\title{
Prognosis and management of polymyalgia rheumatica
}

\author{
J. G. JONES AND B. L. HAZLEMAN \\ From Addenbrooke's Hospital, Hills Road, Cambridge
}

SUMMARY Polymyalgia rheumatica (PMR) is considered to be a benign disease by some, while others think it is a more serious illness which requires similar treatment to giant cell arteritis (GCA). The progress of 85 patients with PMR who presented to a district general hospital has been studied in an attempt to study this relationship. Thirty-eight patients had PMR alone, and 14 developed PMR and GCA within 1 month. Five patients presented with GCA and then developed PMR, and 28 patients developed symptoms of GCA after presenting with PMR (PMR $\rightarrow$ GCA). Arteritis and complications developed up to 9 years after the onset of PMR (mean 1 year). Twenty-two patients (26\%) developed some cerebral or visual complication. Fifteen of these patients were in the PMR $\rightarrow$ GCA group. All 6 patients with permanent loss of vision were in this group. Seven patients developed complications while on corticosteroids. $97 \%$ of patients required corticosteroids for at least 1 year; $32 \%$ of patients still required $10 \mathrm{mg}$ of prednisone or more after 1 year. PMR is not a benign disease.

It is well recognised that polymyalgia rheumatica (PMR) is often a manifestation of giant cell arteritis (GCA), and in some myalgic patients biopsy of an asymptomatic and apparently normal temporal artery may reveal the classical histological appearances of GCA.

The true relationship between PMR and GCA remains uncertain. Some ${ }^{12}$ consider that polymyalgia is always a manifestation of GCA. Others disagree with this view; they point out that most patients with PMR followed up for many years never develop evidence of cranial arteritis and consider it to be a benign condition. ${ }^{3}$ Fauchald et al. ${ }^{1}$ found that $40 \%$ of patients with myalgia alone had a positive biopsy, and other studies suggest that this occurs in $6 \%{ }^{4}$ to $50 \%$ of patients. The cause of this variation is uncertain but may be explained in part by the selection of cases. The interpretation of temporal artery biopsies can be complicated by the presence of skin lesions, which were identified in $28 \%$ of patients with temporal arteritis. ${ }^{6}$ The true incidence of arteritis in polymyalgia is probably higher than reported. The onset of myalgic symptoms may precede, coincide with, or follow that of the arteritic symptoms. No difference has been found between the characteristics of those myalgic patients with a positive biopsy and those with no histological evidence of arteritis. ${ }^{1}$

GCA can lead to blindness, deafness, and cerebral

Accepted for publication 12 March 1980

Correspondence to Dr Hazleman. infarction. These complications are largely preventable by treatment of the disease with adequate doses of corticosteroids. ${ }^{78}$ While the accepted initial dosage for treatment of GCA is $45-60 \mathrm{mg}$ of prednisone a day, ${ }^{9}$ opinions differ on the treatment of patients with PMR alone. Some authors ${ }^{12}$ consider that, as all patients with PMR probably have an underlying arteritis, they should be treated as though they had GCA, that is, with high doses of corticosteroids. Others ${ }^{10} 11$ consider a lower dose of prednisone (10-15 $\mathrm{mg}$ a day) is adequate treatment for those with PMR and no signs of arteritis.

There is also a divergence of views about the length of time for which steroids should be continued. Russell ${ }^{7}$ suggested 6 months' treatment was usually sufficient, and more recently Huston et al. ${ }^{12}$ found that it was possible to withdraw steroids within 1 year from 23 out of 43 patients with positive temporal artery biopsies. Hamilton et al., ${ }^{2}$ however, showed that disabling vascular occlusive episodes may occur from 6 months to 2 years after initiating treatment. Fauchald et al. ${ }^{1}$ recommend treatment for 2 years, and Coomes et al ${ }^{13}$ found that treatment with corticosteroids was necessary for 5 years or longer in $84 \%$ of their patients with PMR.

This study sets out to investigate the association between PMR and GCA in a district hospital population and also attempts to ascertain the incidence of complications and how long corticosteroid therapy is required. 


\section{Jones, Hazleman}

\section{Patients and methods}

Eighty-five patients presenting at Addenbrooke's Hospital between January 1974 and March 1979 have been reviewed. The patients were collected from four sources: (1) from those who underwent temporal artery biopsy; (2) the inpatient diagnostic index; (3) the Polymyalgia Clinic in the Department of Rheumatology; (4) referral from other departments.

A detailed history and examination was carried out if patients met the following criteria.

\section{CRITERIA FOR DIAGNOSIS OF PMR}

(1) Shoulder and pelvic girdle pain which was primarily muscular in the absence of true muscle weakness. (2) Morning stiffness. (3) Duration of at least 2 months unless treated. (4) ESR over $30 \mathrm{~mm} / \mathrm{h}$ or C-reactive protein (CRP) over $6 \mu \mathrm{g} / \mathrm{ml}$. (5) Absence of rheumatoid or inflammatory arthritis or malignant disease. (6) Absence of objective signs of muscle disease. (7) Prompt and dramatic response to systemic corticosteroids.

CRITERIA FOR DIAGNOSIS OF GCA

(1) Positive temporal artery biopsy or cranial artery tenderness noted by a physician. (2) One or more of the following: visual disturbance, headache, jaw pain, cerebrovascular insufficiency. (3) ESR over $30 \mathrm{~mm} / \mathrm{h}$ or CRP over $6 \mu \mathrm{g} / \mathrm{ml}$. (4) Response to corticosteroids.

If a patient with PMR receiving corticosteroids developed symptoms of GCA, a raised ESR or CRP was not considered necessary for diagnosis of GCA. ${ }^{14}$

The initial treatment for patients with GCA was 40-60 mg prednisone a day, and in those patients with no clinical evidence of arteritis $10-15 \mathrm{mg}$ prednisone a day was prescribed. The sedimentation rate was used as a guide to disease activity.

\section{Results}

Patients were divided into 4 groups depending on their clinical symptoms and signs (Table 1). Thirty-

Table 1 Diagnosis of patients and results of temporal artery biopsy

\begin{tabular}{|c|c|c|c|c|c|}
\hline & $\begin{array}{l}\text { Tempora } \\
\text { No. of } \\
\text { patients }\end{array}$ & $\begin{array}{l}\text { artery } \\
\text { Posi- } \\
\text { tive }\end{array}$ & $\begin{array}{l}\text { Nega } \\
\text { tive }\end{array}$ & $\begin{array}{l}\text { Not } \\
\text { performed }\end{array}$ & $\%$ positive \\
\hline $\begin{array}{l}\text { PMR alone } \\
\text { PMR/GCA } \\
\text { PMR } \rightarrow \text { GCA } \\
\text { GCA } \rightarrow \text { PMR }\end{array}$ & $\begin{array}{r}38 \\
14 \\
28 \\
5\end{array}$ & $\begin{array}{r}4 \\
10 \\
7 \\
1\end{array}$ & $\begin{array}{r}11 \\
2 \\
14 \\
4\end{array}$ & $\begin{array}{r}23 \\
2 \\
7 \\
0\end{array}$ & $\begin{array}{l}27 \\
83 \\
33 \\
20\end{array}$ \\
\hline Total & 85 & 22 & 31 & 32 & 41 \\
\hline
\end{tabular}

eight of the 85 patients had symptoms of PMR with no clinical evidence of GCA. Fourteen patients developed signs of both conditions within a month of onset of illness. Twenty-eight patients developed clinical evidence of GCA 1 month or longer after the onset of PMR, and in 5 cases PMR occurred for the first time during treatment for GCA. Thus $28(42 \%)$ of the 66 patients who suffered from PMR alone for at least 1 month developed clinical evidence of GCA. The results of the temporal artery biopsy when performed (Table 1) were positive in $4(27 \%)$ of 15 patients who did not develop clinical evidence of GCA. Three patients in the PMR $\rightarrow$ GCA group (see Table 1) had negative biopsies early in the disease.

The clinical details of the 28 patients who later developed symptoms of GCA are shown (Table 2). Headache was the most prominent symptom. The length of time from onset of PMR to the development of GCA is shown in Fig. 1 (mean interval 1 year; range 1 month-9 years).

Table 3 lists the neurological and visual complications seen in the 4 groups of patients. A serious or potentially serious complication of GCA occurred in $22(26 \%)$ of all 85 patients and in $15(53 \%)$ of 28 patients in the PMR $\rightarrow$ GCA group. Exclusion of the

\begin{tabular}{lrl} 
Table 2 & Clinical features of & $P M R \rightarrow G C A$ group \\
\hline Symptoms & Number \\
\hline Headaches & 23 & (12 with visual symptoms) \\
Meteorism with flare PMR & 1 & (1 with visual symptoms) \\
Jaw pain & 2 & (with visual symptoms) \\
$\begin{array}{l}\text { Swollen face and tender tem- } \\
\text { poral artery }\end{array}$ & 1 & \\
$\begin{array}{l}\text { Prominent tender temporal } \\
\text { artery }\end{array}$ & 1 & \\
\hline
\end{tabular}

Table 3 Neurological and visual complications of 22 patients with PMR

\begin{tabular}{|c|c|c|c|c|}
\hline & $\begin{array}{l}\text { All } \\
\text { patients }\end{array}$ & $\begin{array}{l}P M R / \\
G C A\end{array}$ & $\begin{array}{l}P M R \\
\rightarrow G C A\end{array}$ & $\begin{array}{l}G C A \\
\rightarrow P M R\end{array}$ \\
\hline \multicolumn{5}{|l|}{ Permanent visual } \\
\hline $\begin{array}{l}\text { loss } \\
\text { Temporary visual }\end{array}$ & 6 & & 6 & \\
\hline loss & 7 & & 6 & 1 \\
\hline Temporary visual & & & & \\
\hline blurring & 5 & 2 & 3 & \\
\hline Diplopia & 3 & & 3 & \\
\hline $\begin{array}{l}\text { Permanent lateral } \\
\text { rectus palsy }\end{array}$ & 1 & & 1 & \\
\hline $\begin{array}{l}\text { Transient third } \\
\text { nerve lesion }\end{array}$ & 1 & 1 & & \\
\hline Meteorism & 1 & & 1 & \\
\hline Hemiparesis & 4 & & 3 & 1 \\
\hline $\begin{array}{l}\text { ischaemia } \\
\text { istebrobasilar }\end{array}$ & 1 & 1 & & \\
\hline Vertigo & 2 & & 2 & \\
\hline Deafness & 1 & 1 & & \\
\hline Number of patients & 22 & 5 & 15 & 2 \\
\hline
\end{tabular}

Some patients suffered more than one complication. 


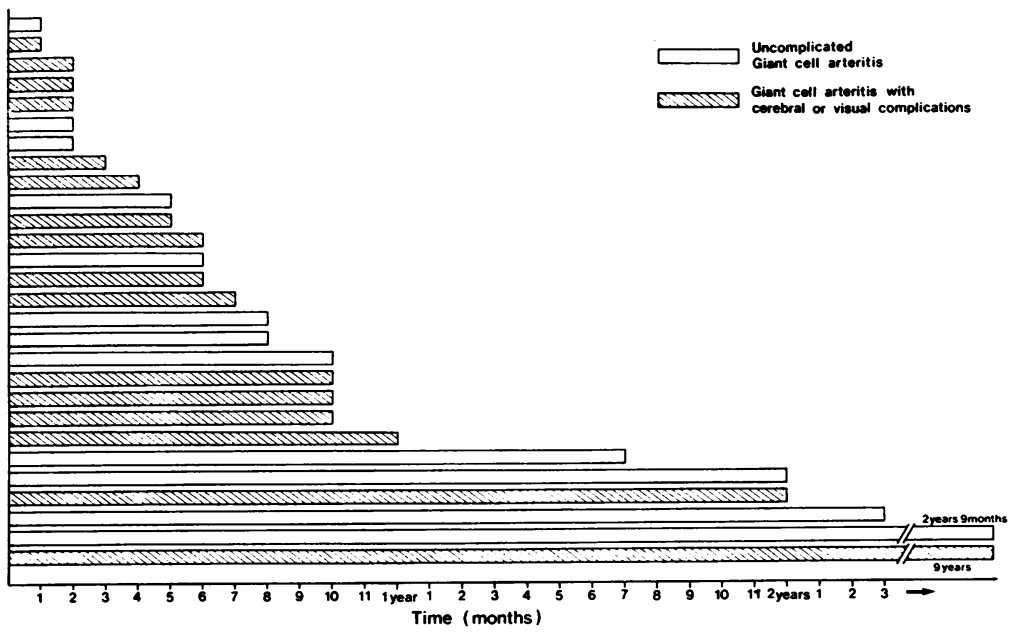

Fig. 1 Interval from onset of $P M R \rrbracket$ to onset of GCA

Table 4 Details of visual and neurological complications

\begin{tabular}{|c|c|c|c|c|c|c|c|c|}
\hline Patient no. & Diagnosis & Complication & $\begin{array}{l}\text { Tim } \\
\text { disec } \\
Y r\end{array}$ & set & $\begin{array}{l}\text { Daily dose } \\
\text { prednisone }\end{array}$ & $\begin{array}{l}\text { Duration of } \\
\text { treatment } \\
Y r\end{array}$ & Mth & $E S R$ \\
\hline 1 & $\mathrm{PMR} \rightarrow \mathrm{GCA}$ & $\begin{array}{l}\text { Hemiparesis, } \\
\text { Transient LOV* }\end{array}$ & & 6 & $12.5 \mathrm{mg}$ & & 2 & 60 \\
\hline 2 & PMR $\rightarrow$ GCA & $\begin{array}{l}\text { Permanent LOV } \\
\text { Lateral rectus palsy }\end{array}$ & & $\begin{array}{l}4 \\
4\end{array}$ & & & & 105 \\
\hline & & Hemiparesis & 1 & 0 & $10 \mathrm{mg}$ & & 7 & 20 \\
\hline 3 & PMR $\rightarrow$ GCA & Permanent LOV & & 8 & $8 \mathrm{ng}$ & & 2 & 3 \\
\hline 4 & PMR $\rightarrow$ GCA & $\begin{array}{l}\text { Transient LOV } \\
\text { Vertigo }\end{array}$ & $4+$ & & $2 \frac{1}{2} \mathrm{mg}$ & 4 & 0 & 42 \\
\hline 5 & GCA $\rightarrow$ PMR & Transient LOV & 2 & 6 & $30 \mathrm{mg}$ & & 3 & 36 \\
\hline 6 & PMR/GCA & Diplopia & 1 & 6 & $7.5 \mathrm{mg}$ & & 9 & ? \\
\hline 7 & PMR/GCA & Blurring & & 2 & $15 \mathrm{mg}$ & & 1 & $?$ \\
\hline 8 & PMR $\rightarrow$ GCA & Meteorism & & 10 & $15 \mathrm{mg}$ & & 3 & 13 \\
\hline 9 & PMR $\rightarrow$ GCA & $\begin{array}{l}\text { Hemiparesis } \\
\text { Transient LOV } \\
\text { Blurring }\end{array}$ & 9 & 0 & $\begin{array}{l}\text { Stopped } 6 \\
\text { month before }\end{array}$ & 8 & 6 & 100 \\
\hline
\end{tabular}

${ }^{*} \mathrm{LOV}=$ Loss of vision.

patients who presented with clinical signs of GCA shows that 15 of $66(23 \%)$ patients who had PMR alone for 1 month or longer went on to develop neurological or visual complications. All 6 patients with permanent visual loss were in this group. Seven out of $19(37 \%)$ patients with clinical evidence of GCA at the onset of their illness developed complications. Eight of the 22 patients developed complications 1 year after disease onset and only 7 patients did so within the first 3 months. Complications occurred in 8 patients while receiving corticosteroids (Table 4 (patients 1-8). Five of these complications occurred less than 4 months after initiation of treatment, while 1 occurred 4 years after starting prednisone. A rise in ESR occurred prior to the onset of complications in 4 out of 7 patients. Patient 9 received $8 \frac{1}{2}$ years' treatment with prednisone for uncomplicated PMR; 6 months after withdrawal of prednisone the patient was
Table 5 Details of visual and neurological complications

\begin{tabular}{|c|c|c|c|c|}
\hline $\begin{array}{l}\text { Patient } \\
\text { no. }\end{array}$ & Diagnosis & Complication & $\begin{array}{c}T i r \\
d i s \\
Y r\end{array}$ & $\begin{array}{l}\text { after } \\
\text { e onset } \\
\text { Mth }\end{array}$ \\
\hline $\begin{array}{l}10 \\
11\end{array}$ & $\begin{array}{l}\text { GCA } \rightarrow \text { PMR } \\
\text { PMR/GCA }\end{array}$ & $\begin{array}{l}\text { Hemiparesis } \\
\text { Vertebrobasilar } \\
\text { insufficiency } \\
\text { Deafness }\end{array}$ & & 1 \\
\hline $\begin{array}{l}12 \\
13 \\
14 \\
15 \\
16\end{array}$ & $\begin{array}{l}\text { PMR } \rightarrow \text { GCA } \\
\text { PMR } \rightarrow \text { GCA } \\
\text { PMR } \rightarrow \text { GCA } \\
\text { PMR } \rightarrow \text { GCA } \\
\text { PMR } \rightarrow \text { GCA }\end{array}$ & $\begin{array}{l}\text { Permanent LOV* } \\
\text { Permanent LOV } \\
\text { Permanent LOV } \\
\text { Permanent LOV } \\
\text { Transient LOV } \\
\text { Diplopia }\end{array}$ & & $\begin{array}{r}10 \\
3 \\
8 \\
6\end{array}$ \\
\hline $\begin{array}{l}17 \\
18\end{array}$ & $\begin{array}{l}\text { PMR } \rightarrow \text { GCA } \\
\text { PMR } \rightarrow \text { GCA }\end{array}$ & $\begin{array}{l}\text { Transient LOV } \\
\text { Transient LOV }\end{array}$ & 1 & 0 \\
\hline 19 & PMR/GCA & $\begin{array}{l}\text { Vertigo } \\
\text { Transient III } \\
\text { Nerve lesion }\end{array}$ & 1 & $\begin{array}{l}7 \\
0\end{array}$ \\
\hline 20 & $\mathbf{P M R} \rightarrow \mathbf{G C A}$ & $\begin{array}{l}\text { Diplopia } \\
\text { Blurring }\end{array}$ & 1 & 7 \\
\hline $\begin{array}{l}21 \\
22\end{array}$ & $\begin{array}{l}\text { PMR } \rightarrow \text { GCA } \\
\text { PMR/GCA }\end{array}$ & $\begin{array}{l}\text { Blurring } \\
\text { Blurring }\end{array}$ & & $\begin{array}{l}2 \\
1\end{array}$ \\
\hline
\end{tabular}

*LOV $=$ Loss of vision. 
Table 6 Details of patients able to stop steroids

\begin{tabular}{|c|c|c|c|c|c|c|c|c|c|}
\hline \multirow[t]{2}{*}{ Patient no. } & \multirow[t]{2}{*}{ Diagnosis } & \multirow[t]{2}{*}{ Initial ESR } & \multirow[t]{2}{*}{ Biopsy } & $\begin{array}{l}\text { Disease duration } \\
\text { before prednisone }\end{array}$ & \multicolumn{2}{|c|}{$\begin{array}{l}\text { Duration of } \\
\text { prednisone }\end{array}$} & \multicolumn{2}{|c|}{ Time off prednisone } & \multirow[t]{2}{*}{ Symptoms } \\
\hline & & & & $Y r \quad M t h$ & $Y r$ & $M t h$ & $Y r$ & Mth & \\
\hline 23 & PMR/GCA & 117 & ND & 9 & & 9 & 2 & 6 & 0 \\
\hline 24 & PMR & 33 & ND & 4 & 1 & 7 & 2 & 9 & 0 \\
\hline 25 & PMR & 130 & + & 2 & 1 & 5 & 3 & 0 & $\mathbf{S}$ \\
\hline 26 & PMR & 74 & ND & 3 & & 9 & 2 & 6 & 0 \\
\hline 27 & PMR/GCA & 77 & ND & 1 & 1 & 9 & & 6 & $\mathbf{S}$ \\
\hline 29 & PMR/GCA & 40 & + & 2 & 3 & 8 & & 6 & $\mathbf{S}$ \\
\hline
\end{tabular}

Pred. $=$ prednisone. Biopsy results: $+=$ positive; ND $=$ not done. Symptoms: $0-$ No symptoms; $\mathbf{S}=$ symptoms (see text).

admitted to hospital with bitemporal headaches, hemiplegia, and transient blurring of vision. The ESR was elevated at $100 \mathrm{~mm} / \mathrm{h}$ and a temporal artery biopsy was positive. Reintroduction of corticosteroids controlled the symptoms, and 2 years later $10 \mathrm{mg}$ of prednisone was still required.

Six patients did not receive corticosteroids because the symptoms were mild or they had a history of previous gastrointestinal haemorrhage or tuberculosis. Only 7 of the remaining patients had been able to discontinue corticosteroid therapy (Table 6). Two patients stopped treatment at 9 months and have remained free of symptoms. Three patients stopped treatment after 1 year, and treatment was withdrawn after 3 years in the other 2 patients. The clinical and laboratory features of those 7 patients at onset were similar to the rest of the group. Three patients still have some stiffness or occasional tender scalp nodules. Corticosteroids were withdrawn in 7 further patients, but recurrence of their symptoms necessitated reinstitution of treatment. In 2 cases this was less than 1 year after starting treatment, in 3 after 1 year of treatment, and in the other 2 it was after $3 \frac{3}{4}$ and $8 \frac{1}{2}$ years of treatment respectively.

Seventy-two patients were taking prednisone at the time of interview. Thirteen patients had received treatment for less than 1 year, 59 patients for over 1 year, 34 had been treated for 2 years, and 21 for at least 3 years. Interpretation of these figures is made difficult by the varying duration of follow-up, but 21 of the 59 patients who received treatment for at least 1 year required $10 \mathrm{mg}$ of prednisone a day or more. Thirty-three patients were taking between 5 and $9 \mathrm{mg}$ a day, and only 5 patients received less than $5 \mathrm{mg}$ of prednisone a day.

Only 11 patients had not suffered a definite relapse on reduction of corticosteroid dosage. Forty of the 55 patients who developed a definite relapse on reduction of their prednisone did so at least 1 year after starting treatment, and 23 patients had relapsed 2 years or more after beginning treatment.

\section{Discussion}

In this group of hospital patients PMR does not appear to be a benign disease. Clinical evidence of GCA was seen in $55 \%$ of all patients with PMR, and serious or potentially serious neurological or visual complications occurred in $26 \%$ of cases. $44 \%$ of myalgic patients with no clinical evidence of GCA in the early stages of the disease developed GCA, and $23 \%$ of these patients suffered complications. All 6 patients with permanent loss of vision were in the latter group, as were the 3 of the 5 patients who developed cerebrovascular ischaemia. Arteritis and complications developed up to 9 years after the onset of PMR (mean 1 year; range 1 month to 9 years).

The complication rate in this group of hospital patients is high and may exaggerate the morbidity of the disease in the community. While some general practitioners refer all patients with PMR to hospital, others treat straightforward cases at home and refer only the more complicated ones to hospital. Thus any series of hospital patients is likely to contain more patients with complications than a series produced from general practice. On the other hand, the definition of PMR used in the series (involvement of both upper and lower limbs) is more stringent than in other series, which include patients with involvement of the upper or lower extremities alone. Our definition is more likely to exclude those patients with degenerative joint disease, capsulitis of the shoulders, or spinal disorders and may reflect a more classical disease pattern. This group of patients has been drawn from all departments of the hospital, which removes the bias of a series from 1 specialty. For example, a series from an ophthalmology department will have more patients with visual complications than a series from a rheumatology unit. Even when these considerations are taken into account, a complication rate of $26 \%$ is surprisingly high.

Complications developed at least 3 months after the onset of illness in 13 of the 15 cases without 
initial evidence of arteritis. Harrison and Bevan ${ }^{15}$ described 9 patients who developed GCA at least 1 year after onset of PMR. One case suffered some visual loss and another developed a hemiplegia. Seven out of 15 cases reported by Olhagen ${ }^{16}$ developed localised changes of arteritis 3 to 27 months afcer the onset of PMR, and in 3 cases visual impairment was present. Unlike those cases who present with symptoms of GCA, where complications usually develop under 3 months, ${ }^{78}$ it appears that complications often develop at longer intervals in patients with PMR.

Temporal artery biopsy was of no value in predicting which patients would be likely to develop signs of GCA. Three patients with PMR who later developed GCA had negative biopsies before the onset of clinical evidence of GCA, and 4 out of 15 biopsies were positive in myalgic patients who never showed clinical evidence of arteritis.

Corticosteroid therapy did not prevent the development $\mathrm{cf}$ arteritis in 8 cases, though signs of GCA did occur for the first time after withdrawal of corticosteroids in 2 cases. Complications developed in 8 patients while on corticosteroids, and in 3 of these patients the ESR was not raised when the complication occurred. Five of these patients developed complications less than 3 months after beginning corticosteroids. While 1 patient was taking $30 \mathrm{mg}$ of prednisone a day, the other 4 were taking less than $15 \mathrm{mg}$ a day. If these patients had been receiving a high-dose prednisone programme of treatment, it is possible that these episodes might not have happened. It is noteworthy that 1 patient permanently lost vision, and other patients suffered a hemiparesis.

The high incidence of complications in this series tends to support the belief of Hamilton et al. ${ }^{2}$ and Fauchald et al. ${ }^{1}$ that all patients with PMR should be treated with high doses of corticosteroids as though they had GCA. However, it should be emphasised that $58 \%$ of patients who presented with PMR and received low doses of prednisone have showed no evidence of GCA. The side effects caused by high dose corticosteroids in this elderly group of patients will produce a morbidity and mortality of their own, and this must be weighed against severity of the disease itself.

The disease relapsed in $\mathbf{4 0}$ patients a year after starting therapy, and we found that $97 \%$ of patients required corticosteroids for at least 1 year. Although the dosage of corticosteroids was kept as low as possible, $32 \%$ of patients still required $10 \mathrm{mg}$ of prednisone or more after 1 year's treatment.
This study supports the view that PMR is not a benign disease. Patients require regular follow-up and should be instructed to report to their doctor if there is any exacerbation of their myalgia or if there are visual symptoms. The clinician should be alert to the development of signs of GCA at any time in the long course of this disease and not become complacent in the management of the apparently fit corticosteroid-treated patient. At present there is no method of predicting those patients who will develop complications of their disease.

We thank the Arthritis and Rheumatism Council for support and the clinicians at Addenbrooke's Hospital for referring their patients.

\section{References}

1 Fauchald P, Rygvold O, Oystese B. Temporal arteritis and polymyalgia rheumatica. Clinical and biopsy findings. Ann Intern Med 1972; 77: 845-52.

2 Hamilton C R, Shelley W M, Tumulty P A. Giant cell arteritis including temporal arteritis and polymyalgia rheumatica. Medicine (Baltimore) 1971 ; 50: 1-27.

3 Ettlinger R E, Hunder G G, Ward E L. Polymyalgia rheumatica and giant cell arteritis. Ann Rev Med 1978; 29: 15-22.

4 Hunder G G, Allen G L. The relationship between polymyalgia and temporal arteritis. Geriatrics 1973; 28: 134-42.

5 Malmvall B E, Bengtsson B A. Giant cell arteritis: clinical features and involvement of different organs. Scand J Rheumatol 1978; 7: 154-8.

- Klein R G, Campbell R J, Hunder G G, et al. Skip lesions in temporal arteritis. Mayo Clin Proc 1976; 51 : 504-8.

7 Russell R W R. Giant cell arteritis-a review of 35 cases. Q J Med 1958; 28: 471-89.

8 Hollenhorst R W, Brown J R, Wagner H P, Schick R M. Neuralgic aspects of temporal arteritis. Neurology 1960; 10: $490-8$.

9 Hunder G G, Allen G L. Giant cell arteritis: a review. Bull Rheum Lis 1978-9; 29: 980-6.

10 Healey L A, Wilske K R. Manifestations of giant cell arteritis. Med Clin N Am 1977; 61: 261-70.

11 Myles A B. Polymyalgia rheumatica and giant cell arteritis: a seven year survey. Rheumatol Rehabil 1975;14: 231-5.

12 Huston $K A$, Hunder $G$ G, Lie J T, Kennedy R H, Elverback L R. Temporal arteritis: a 25 year epidemiologic, clinical and pathologic study. Ann Intern Med 1978; 88: 162-7.

13 Coomes E N, Ellis R M, Kay A G. A prospective study of 102 patients with polymyalgia rheumatica syndrome. Rheumatol Rehabil 1976; 15: 270-6.

14 Rynes R I, Mika P, Bartholomew L E. Development of giant cell (temporal) arteritis in a patient 'adequately' treated for polymyalgia rheumatica. Ann Rheum Dis 1977; 36: 88-90.

15 Harrison M J G, Bevan A T. Early symptoms of temporal arteritis. Lancet 1967; ii: 638-40.

16 Olhagen B. Polymyalgia rheumatica a form of senile arteritis? Acta Rheumatol Scand 1963; 9: 157-64. 